\title{
EVALUATION OF THE PROCESS OF IMPLEMENTING TAHFIDZ AL-QUR'AN LEARNING PROGRAMS IN INTEGRATED ISLAMIC BASIC SCHOOLS OF DOD DELI SERDANG
}

\section{EVALUASI PROSES PELAKSANAAN PROGRAM PEMBELAJARAN TAHFIZH AL-QUR'AN DI SEKOLAH DASAR ISLAM TERPADU DOD DELI SERDANG}

\author{
Fakhruddin Azmi ${ }^{1}$, Mesiono $^{2}$, and Abd Rahman ${ }^{3}$ \\ ${ }^{1}$ State Islamic University of North Sumatera \\ ${ }^{2}$ State Islamic University of North Sumatera \\ ${ }^{3}$ State Islamic University of North Sumatera \\ email:fakhruddinazmi@gmail.com \\ email:mesiono@uinsu.ac.id \\ email:7889rahman@gmail.com
}

Received: 27/05/2020, Accepted: 20/08/2020, Published: 29/08/2020

\begin{abstract}
This study aims to evaluate the implementation process of the tahfizh Alquran learning program at SDIT DOD Deli Serdang through one of the components of the CIPP evaluation model, namely, Process Evaluation. The research question is focused on; 1 . How is the implementation of the Tahfzih Al-Quran learning program? 2. What are the supporting factors for the implementation of the Tahfzih Al-Quran Learning Program, and 3. What are the inhibiting factors for the implementation of the Tahfzih Al-Quran learning program at SDIT DOD Deli Serdang? This research was conducted at SDIT DOD Deli Serdang. This study used a qualitative research method with an evaluation approach as the blade of analysis. Sources of data were obtained from the head of the foundation, the principal, the deputy principal, the tahfizh teachers, the homeroom teacher and assistant, the students' parents, and the students, through three methods, namely observation, interviews, and documents. The results of this study are that the implementation of the program has not been as planned, the teacher has not mastered the learning material, the learning method varies with the adjustment of the student's ability level, has not used electronic-based learning media, the students have not been able to follow the memorization target, and not all students can repeat/learn' ah memorization. Supporting factors for the Alquran tahfizh program at SDIT DOD Deli Serdang; The willingness of teachers to improve the quality of themselves in tahsin and tahfizh of the Koran, concern for parents, the establishment of a tahfizh Al-Quran learning program as part of the school's vision and mission, the enthusiasm of teachers in improving self-quality in reading and memorizing the Koran, communication between teachers and parents. Inhibiting factors for the Alquran tahfizh program at SDIT DOD Deli Serdang; Lack of budget, teacher quality, transfer students, teacher attendance, teacher ability, parents' ability Koran, school facilities, on average students have career parents. There is no awareness of students to repeat their memorization.
\end{abstract}

Keywords: evaluation; process; tahfizh Al-Qur'an. 


\begin{abstract}
ABSTRAK
Penelitian ini bertujuan untuk mengevaluasi proses penyelenggaraan program pembelajaran tahfizh Alquran di SDIT DOD Deli Serdang melalui salah satu komponen model evaluasi CIPP yaitu Evaluasi Proses. Pertanyaan penelitian difokuskan pada; 1. Bagaimana pelaksanaan program pembelajaran Tahfzih Alquran, 2. Apa faktor pendukung pelaksanaan Program Pembelajaran Tahfzih Alquran, dan 3. Apa faktor penghambat pelaksanaan program pembelajaran Tahfzih Alquran di SDIT DOD Deli Serdang. Penelitian ini dilaksanankan di SDIT DOD Deli Serdang, penelitian ini menggunakan metode penelitian kualitatif dengan pendekatan evaluasi sebagai pisau analisisnya. Sumber data didapat dari ketua yayasan, kepala sekolah, wakil kepala sekolah, guru-guru tahfizh, wali kelas dan asisten, orang tua siswa dan siswa, melalui tiga cara yaitu observasi, wawancara dan dokumen. Hasil penelitian ini adalah bahwa pelaksanaan program belum sesuai dengan yang direncanakan, guru belum menguasai materi pembelajaran, metode pembelajaran bervariasi dengan penyesuaian tingkat kemampuan siswa, belum menggunaan media pembelajaran berbasis elektronik, siswa belum mampu mengikuti target hafalan dan belum semua siswa mampu mengulang/muraja'ah hafalannya. Faktor pendukung program tahfizh Alquran di SDIT DOD Deli Serdang; Kemauan guru dalam memperbaiki kualitas diri mereka dalam tahsin dan tahfizh Alquran, kepedulian orang tua, penetapan program pembelajaran tahfizh Alquran sebagai bagian dari visi misi sekolah, semangat guru-guru dalam memperbaiki kualitas diri dalam membaca dan menghafal Alquran, Komunikasi antar guru dan orang tua. Faktor penghambat program tahfizh Alquran di SDIT DOD Deli Serdang; Minimnya anggaran, kualitas guru, siswa pindahan, kehadiran guru, kemampuan guru, kemampuan Alquran orang tua, fasilitas sekolah, rata-rata siswa memiliki orang tua karir, belum ada kesadaran siswa untuk mengulang hafalan sendiri.

Kata kunci: evaluasi; proses; tahfizh Al-Qur'an.
\end{abstract}

\section{A. PENDAHULUAN}

Menghafal (tahfizh) Al-Qur'an adalah suatu upaya yang dilakukan melalui sebuah proses menghafal, memelihara, menjaga dan mengokohkan serta menguatkan bacaan ayat-ayat Alquran di dalam dada manusia, sehingga mampu menghadirkan atau membacakan ayat-ayat Al-Qur'an tersebut kapan saja dia kehendaki tanpa harus melihat mushaf Al-Qur'an terlebih dahulu.

Manna Al-Qattan mengungkapkan bahwa mengandalkan kekuatan hafalan hati dan dada dalam menukil Al-Qur'an, bukan melalui tulisan mushaf dan kitab, adalah ciri khas paling mulia yang Allah S.W.T. berikan kepada umat ini (Manna' Al-
Qatthan, 2017: 193). Menghafal Al-Qur'an adalah upaya pengumpulan ayat-ayat AlQur'an yang pertama dilakukan oleh Rasulullah dan para sahabatnya.

Tujuan filosofis dan praktis pembelajaran tahfizh Al-Qur'an adalah; (1) Agar siswa mampu membaca Al-Qur'an dengan fasih dan lancar tanpa melihat mushaf. (2) Sebagai upaya penguatan dan pengkondisian moralitas, pembiasaan hidup bersama Al-Qur'an sehingga dapat mencintainya dan benar-benar tumbuh sebagai generasi yang quraniy (Lukman Hakim, 2012: 72).

Tujuan selanjutnya adalah (3) Agar mampu melafalkan Al-Qur'an dengan baik 
dan benar tanpa melihat kitab Alquran, (4) Agar mampu melafalkan Al-Qur'an secara urut ayat demi ayat, (5) Agar mampu melanjutkan penggalan bacaan ayat AlQur'an, (6) Agar mampu mengoreksi kesalahan hafalan/ bacaan yang dilafalkan orang lain (Heri Saptadi, 2012: 119).

Terpeliharanya Al-Qur'an dari segala bentuk penambahan dan pengurangannya merupakan janji Allah S.W.T. beberapa ratus ribu tahun yang lalu yang kini janji itu telah menadi bukti. Kalimat lahafizhun merupakan janji Allah untuk memeliharanya M. Quraish Shihab, 2009: 422). Berbeda dengan kitab-kitab sebelumnya, di mana pemeliharaan kitab suci hanya dilakukan oleh umatnya masingmasing tanpa ada keterlibatan Allah S.W.T., sehingga kelalaian dan kelengahan umat tersebut membuat otentitas kitab tersebut menjadi keliru seperti yang Allah S.W.T. gambarkan dalam Al-Qur'an Q.S. Al-Maidah: 44.

Pada dasarnya evaluasi proses dilakukan untuk memeriksa pelaksanaan program yang sebelumnya telah ditetapkan dalam perencanaan program. Tujuannya adalah memberikan masukan bagi pengelola dan/atau implementator tentang kesesuaian antara pelaksanaan dengan apa yang direncanakan, baik dari segi jadwal, sumber daya manusia, strategi yang dihunakan, dan lain sebagainya terkait proses pelaksanaan program.

Dalam salah satu journal internasional disebutkan bahwa Evaluasi proses memonitor proses implementasi proyek. Pertanyaan yang tepat pada evaluasi ini adalah "Apakah yang sedang dilakukan?". Evaluasi ini memberikan pemeriksaan berkelanjutan pada proses implementasi proyek. Tujuan penting dari evaluasi proses termasuk mendokumentasikan proses dan memberikan umpan balik mengenai (a) sejauh mana kegiatan yang direncanakan dilakukan dan (b) apakah penyesuaian atau revisi rencana diperlukan (Guili Zhang, dkk., 2011: 62).

Evaluasi proses bertujuan untuk memastikan prosesnya dan menjelaskan penyimpangan-penyimpangan dari rencana semula. Evaluasi proses meningkatkan peluang bagi kurikulum untuk secara teratur menilai area yang diterapkan dengan benar dan efisien. Ini digunakan untuk memprediksi kesulitan dan untuk menerima umpan balik tentang perubahan penting yang perlu dilakukan dalam pelaksanaan program dan untuk memberikan keputusan lainnya karena evaluasi proses mengamati proses implementasi kurikulum (Ezgi Darama, dkk., 2018: 77). 
Sekolah Islam Terpadu merupakan sekolah yang diselenggarakan dengan memadukan secara Integratif antara nilai dan ajaran Islam dalam bangunan kurikulum Islam terpadu sehingga tidak ada istilah dikotomi pendidikan dengan pendekatan pembelajaran yang efektif, serta melibatkan upaya yang optimal dan koperatif antara guru dan orangtua, serta masyarakat untuk membina karakter dan kompetensi peserta didik sehingga cerdas dalam IQ, EQ dan SQ serta mampu beramal secara ihsan (Fahmi Alaydroes, dkk., t.t.: 5).

Istilah "Terpadu" dalam SIT dimaksudkan sebagai penguat (taukid) dari Islam itu sendiri. Maksudnya adalah Islam yang utuh menyeluruh, Integral, bukan parsial, syumuliah bukan juz'iyah. Hal ini menjadi semangat utama dalam gerak $d a$ 'wah dibidang pendidikan ini sebagai "perlawanan" terhadap pemahaman sekuler, dikotomi, juz'iyah (Fahmi Alaydroes, dkk., t.t.: 5).

Selain itu, sebagai lembaga pendidik yang sangat perhatian akan keagamaan, juga memiliki ketentuan dalam progres pendidikan (Saihu dan Baeti Rohman, 2019: 439). Salah satu program pembelajaran di Sekolah Islam Terpadu adalah pembelajaran tahfizh Al-Qur'an. Sekolah Dasar Islam Terpadu memang sangat memungkinkan melaksanakan pembelajaran tahfizh Al-Qur'an karena sistem sekolah yang dikelola dengan model full day school (FDS). Ini merupakan sebuah sistem yang sangat dibutuhkan dalam pengelolaan program pembelajaran tahfizh Al-Qur'an. Karena kegiatan tahfizh Al-Qur'an memerlukan kekonsistenan, waktu yang luang, pengajar, sistem pembelajaran yang jelas, serta harus dilaksanakan berdasarkan program yang jelas (Ani Nur Aeni, 2017: 37).

Capaian hafalan yang seharusnya dilaksanakan oleh Sekolah Islam Terpadu adalah mampu menghafal Al-Qur'an (tahfizhul quran) dengan standar minimal dua juz setiap tingkatan satuan pendidikan (Fahmi Alaydroes, dkk., t.t.: 7). Ini merupakan misi dari sekolah Islam terpadu yang dapat dipahamai bahwa target pencapaian pada pembelajaran tahfzih AlQur'an di Sekolah Islam Terpadu adalah dua Juz Al-Qur'an. Ini berarti secara gamblang dapat dikatakan bahwa setiap siswa yang duduk di Kelas VI Sekolah Dasar Islam Terpadu telah memiliki hafalan Al-Qur'an sebanyak dua Juz Al-Qur'an.

Dalam pelaksanaan program, guru adalah kunci utama. Kriteria guru tahfizh dalam standart Jaringan Sekolah Islam Terpadu adalah pendidik dengan kualifikasi ijazah minimal lulusan SMA/MA sederajat, namun, pendidik yang hanya lulusan 
SMA/MA sederajat ini harus memiliki hafalan Al-Qur'an 30 Juz yang dibuktikan dengan Sertifikat Hafalan (Fahmi Alaydroes, dkk., t.t.: 15).

Muhammad yakub Zulkifli dan Muhammad Yusuf Nurdin Ahmad (2016) mengungkapkan, bahwa dalam pembelajaran tahfizh Al-Qur'an untuk menjadi seorang guru tahfizh yang handal, seseorang harus memiliki kompetensi dalam dua hal yaitu:

a. Bidang konten yaitu guru tahfizh perlu menguasai kandungan mata pelajaran yang berkaitan dengan Al-Qur'an, memiliki kemampuan bacaan Al-Qur'an yang dapat membaca dengan tajwid yang betul, di samping itu dapat menguasai teori ilmu tajwid dengan baik.

b. Bidang pedagogi yaitu guru perlu memliki pengetahuan tentang teknik, strategi dan metode pengajaran yang dilakukan untuk memastikan objektif pengajaran tercapai, dan hal lain sebagainya.

Terkait dengan metode pelaksanaan program pembelajaran tahfizh Al-Qur'an di SDIT DOD Deli Serdang oleh guru-guru tahfizh, peneliti melihat guru tahfizh menerapkan berbagai metode penghafalan yang bervariatif, meskipun perlu kritik dan saran terhadap metode-metode tersebut agar dapat menjadi perbaikan-perbaikan selanjutnya. Salah satu metode yang sering digunakan dalam pembelajaran tahfizh AlQur'an adalah metode talaqqi.

Talaqqi atau Talqin secara bahasa berarti memahamkan, sedangkan menurut istilah adalah seorang pendidik mengajarkan ucapan, kata-kata atau ayat dalam Al-Qur'an yang kemudian ditirukan oleh peserta didik atau pendengar. Apabila ada kekeliruan, kekurangan atau kesalahan dalam pelafalan atau pengucapan seperti pada hukum mad wal qashar (panjang pendek), makhraj al-huruf dan sifat huruf maka seorang pendidik dapat langsung memperbaikinya (Hasan Bisri, 2018: 66$67)$.

Terkait dengan media pembelajaran dapat dikatakan bahwa sesuai dengan hasil penelitian baik melalui wawancara dan observasi peneliti menyimpulkan media pembelajaran pada program pembelajaran tahfizh Al-Qur'an di SDIT SD Deli Serdang belum mendapatkan perhatian serius dari pihak pengelola. Sehingga kesimpulan pada penelitian ini adalah media pembelajaran merupakan bagian dari kendala pelaksanaan program pembelajaran Tahfizh Al-Qur'an di SDIT DOD Deli Serdang.

Media pembelajaran adalah satu kata yang merangkum beberapa makna 
pengantar penmebalajaran seperti; alat peraga yaitu alat (benda) yang digunakan untuk memperagakan fakta, konsep, prinsip atau prosedur tertentu agar tampak lebih nyata/ konkrit; Alat bantu yaitu alat (benda) yang digunakan oleh pembelajar untuk mempermudah tugas dalam mengajar; Audio-Visual Aids (AVA) yaitu alat bantu yang mempunyai pengertian dan tujuan yang sama hanya saja penekanannya pada peralatan audio dan visual. Sedangkan alat bantu belajar penekanannya pada pihak yang belajar (pembelajar) (Wan Falahudin, 2014: 109).

Menurut peneliti, di era teknologi ini, banyak media pembelajaran yang dapat dimanfaatkan dalam pelaksanaan program pembelajaran tahfizh Al-Qur'an. Luasnya makna Al-Qur'an sebagai matei hafalan seharusnya mempermudah pembimbing dalam menyediakan media pembelajaran Tahfizh Al-Qur'an sehingga program pembelajaran tahfizh Al-Qur'an bukanlah pembelajaran yang membosankan.

Permasalahan terkait kemampuan siswa menyetorkan hafalannya sesuai target hafalan setiap harinya perlu mendapat sorotan. Pembuatan target hafalan perhari sangat dibutuhkan agar pencapaian bisa dikontrol. Target hafalan harus dibuat mulai dari target paling besar sampai target paling kecil yaitu menentukan target per 6 tahun, pertahun, persemester, perbulan, perminggu sampai perhari. Target capaian harian, mingguan, bulanan, semesteran, tahunan harus jelas, karena dengan itu pengelola dan pembimbing akan bisa menentukan kapan mau dimulai dan kapan akan diselesaikan (Saied Al-Makhtum dan YadiIradi, 2017: $57)$.

Permasalahan terakhir adalah terkait dengan muroa'ah hafalan. Muraja'ah secara bahasa adalah pembiasaan. Sedangkan menurut istilah adalah kegiatan yang bertujuan untuk mengulang-ulang hafalan Al-Qur'an yang telah dihafal. Muraja'ah harus dilakukan dan wajib bagi para penghafal Al-Qur'an dengan keistiqamahan dan ketekunan untuk mencegah lupa atau hilangnya hafalan (Hasan Bisri, 2018: 68). Muraja'ah ini harus dilakukan di sekolah dan di rumah. Mengulang hafalan atau muraja'ah di rumah akan berakibat pada kelancaran hafalan siswa itu sendiri yang juga berakibat pada pencapaian target hafalan yang belum tercapai dengan semaksimal mungkin.

Lain halnya dengan muraja'ah di sekolah, terkait dengan hal ini, kemampuan siswa dalam melaksanakan kegiatan muraja'ah hafalan di sekolah secara bersama-sama, peneliti melihat dari hasil observasi bahwasanya kebanyakan siswa mampu mengulang dan mengikuti kegiatan 
muraja'ah bersama-sama di kelas meskipun masih terlihat ada yang tersendat hafalannya karena faktor lupa namun dapat dikatakan mereka bisa melaksanakan kegiatan di kelas sesuai dengan kriteria yang ditetapkan.

\section{B. METODE PENELITIAN}

Penelitian ini dilakukan di Sekolah Dasar Islam Terpadu SDIT DOD Deli Serdang, Sumatera Utara yang bertujuan untuk mengetahui dan menganalisis terkait 1. Pelaksanaan Program pembelajarann tahfizh Al-Qur'an di SDIT DOD Deli Serdang, 2. Faktor pendukung proses pelaksanaan program pembelajaran tahfizh Al-Qur'an, dan 3. Faktor penghambat proses pelaksanaan program pembelajaran tahfizh Al-Qur'an di SDIT DOD Deli Serdang.

Penelitian ini menggunakan metode penelitian kualitatif dengan menggunakan pendekatan evaluasi sebagai pisau analisisnya. Model evaluasi yang peneliti pilih adalah evaluassi model CIPP (Contex, Input, Proces, and Pruduct). Evaluasi dari ke empat komponen model evaluasi CIPP tersebut, penelitian ini memfokuskan pembahasan pada evaluasi proses.

Data dan sumber data primer didapat dari ketua yayasan, kepala sekolah, wakil kepala sekolah bidang kurikulum, wakil kepala sekolah bidang kesiswaan, wakil kepala sekolah bidang tahfizh atau koordinator tahfizh, guru-guru tahfizh atau wali kelas, asisten wali kelas, Ketua JSIT Wilayah Sumatera Utara, orang tua siswa, siswa. Adapun sumber data sekunder dari masyarakat sekitar, BKM Mesjid sekitar sekolah, Sekolah tujuan alumni SDIT DOD Deli Serdang.

Data-data penelitian akan diperoleh melalui tiga cara yaitu observasi, wawancara dan dokumen (Jhon W. Creswell, 2003: 181). Wawancara dalam penelitian ini dilakukan dengan tiga model wawancara, yaitu: Wawancara terbuka, wawancara terstruktur dan wawancara mendalam. Adapun aktivitas-aktivitas dalam analisis data pada penelitian ini adalah data reduction, data display dan conclusion drawing/verification. Prosedur analisis data dalam penelitian ini adalah dengan mengikuti langkah-langkah evaluasi model CIPP yang difokuskan pada evaluasi konteks. Adapun tehnik untuk memperoleh keabsahan data penelitian yang telah terkumpul adalah dengan menentukan empat kriteria berikut yaitu: uji kredibilitas data, uji transferability, uji dependability dan uji konfirmability (kepastian). 


\section{PEMBAHASAN}

1. Analisis kriteria pelaksanaan program sekolah SDIT DOD Deli

\section{Serdang.}

a. Pelaksanaan program sesuai dengan yang direncanakan.

Pelaksanaan sebuah program pembelajaran yang telah ditetapkan diharapkan sejalan dengan apa yang direncanakan yaitu bisa mencapai sebuah tujuan yang diinginkan. Hal yang demikian juga diharapkan bisa berjalan pada program pembelajaran tahfizh Al-Qur'an di SDIT DOD Deli Serdang. Dalam wawancara Kepala sekolah menjelaskan, bahwa pelaksanaan program pembelajaran tahfizh Al-Qur'an di SDIT DOD Deli Serdang belum sesuai dengan apa yang direncanakan. Ketidaksesuaian ini terlihat dari dua faktor yaitu ketidak tercapaian target hafalan dan ketidakpuasan terhadap bacaan Al-Qur'an siswa.

Lebih lanjut Kepala sekolah menambahkan bahwa pelaksanaan program pembelajaran tahfizh Al-Qur'an awalnya dilakukan dengan berkelompok-kelompok yaitu 1 kelompok di isi oleh 10 siswa dan dibimbing oleh 1 guru. Ketidak efektifan sistem kelompok ini membuat kepala sekolah menghadirkan sistem baru yaitu melaksanakan program pembelajaran tahfizh Al-Qur'an di kelas masing-masing dengan diasuh oleh 2 orang guru setiap kelasnya.

Sri Rahayu selaku wali kelas menjelaskan, bahwa pelaksanaan program pembelajaran tahfizh Al-Qur'an belum seperti yang diinginkan. Menurutnya, pelaksanaan program pembelajaran tahfizh Al-Qur'an di SDIT DOD Deli Serdang belum sesuai dengan apa yang direncanakan. Pada perencanaan target capaian, alumni SDIT DOD Deli Serdang diharapkan mampu memiliki hafalan minimal 2 Juz Al-Qur'an, namun faktanya hanya mampu menghafal 1 Juz Al-Qur'an.

Hal serupa juga disampaikan oleh wali Kelas V Umar Bin Khattab, menurutnya bahwa pelaksanaan program pembelajaran tahfizh Al-Qur'an di SDIT DOD Deli Serdang belum sesuai dengan apa yang direncanakan. Pihak sekolah merencanakan target capaian itu 2 Juz Al-Qur'an dan 2 Juz Alquran tersebut seyogyanya telah dapat dicapai di saat siswa duduk di bangku Kelas V. Hal ini diupayakan agar siswa tersebut ketika duduk di bangku Kelas VI tidak lagi menambah hafalan Al-Qur'an, cukup mengulang-ulang hafalan karena harus focus mempersiapkan diri untuk Ujian Nasional. 
b. Guru menguasai materi pembelajaran.

Sebagai seorang guru, sebelum memahamkan sebuah pelajaran kepada siswanya, tentunya seorang guru harus menguasai materi yang akan diajarkan tersebut. Dalam program pembelajaran tahfizh Al-Qur'an, yang dimaksud dengan penguasaan materi di sini adalah kuantitas dan kualitas hafalan guru lebih banyak dari siswanya sehingga materi tahfizh yang akan diajarkan kepada siswa telah dihafal oleh gurunya terlebih dahulu.

Kepala sekolah SDIT DOD Deli Serdang menjelaskan bahwa kendala besar bagi sekolah SDIT DOD Deli Serdang adalah belum memiliki guru tahfizh yang ideal ditinjau dari hafalan Al-Qur'an. Minimnya anggaran menjadi faktor utama akan ketidak-mampuan sekolah menghadirkan sumber daya manusia yang ideal yang bisa menguasai materi pembelajaran tahfizh Al-Qur'an. Akibat dari ketiadaan SDM yang mumpuni ini adalah metode tasmi' hafalan yang mengharuskan guru melihat mushaf AlQur'an.

Wali kelas yang bertugas sebagai guru tahfizh, memaparkan bahwa penguasaan materi pembelajaran pada program pembelajaran tahfizh Al-Qur'an masih sejalan dengan apa yang dihafal oleh siswa- siswinya yaitu di Juz 30. Persamaan jumlah kuantitas hafalan ini membuatnya sedikit tertinggal dengan hafalan siswa yang sudah masuk ke Juz 29. Akibatnya dia harus melihat mushaf saat mendengarkan siswanya setor hafalan di juz 29. Tanpa disadarinya bahwa ini sebuah kendala dalam program pembelajaran tahfizh AlQur'an, beliau menganggap ini sebuah keuntungan yang bisa diamanfaatkan guna menambah hafalan.

Dalam sebuah observasi ke salah satu kelas, peneliti melihat proses setor hafalan yang dilakukan oleh siswa siswi kepada guru tahfizhnya. Pada pengamatan kali ini, peneliti sendiri melihat salah satu guru tahfizh yang mendengarkan siswanya setor hafalan dengan melihat mushaf Al-Qur'an. Dari proses setor hafalan seperti ini, seakan guru tahfizh tersebut belum menguasai dengan benar materi pembelajaran yang sedang dilaksanakan, sehingga mereka perlu melihat mushaf Al-Qur'an kembali ketika mendengarkan siswanya setor hafalan.

c. Metode pembelajaran

Wali kelas selaku petugas guru tahfizh menjelaskan bahwa metode yang digunakan adalah metode talaqqi dengan memotong-motong ayat. Metode ini digunakan pada Kelas I. Ada beberapa langkah yang ditempuh oleh wali kelas 1 ini 
dalam menggunakan metode ini. Sebagai contoh pada Surah Al-Fiil Ayat 1 sebagaimana yang dielaskan di atas, langkah-langkahnya adalah:

1) Menentukan ayat yang akan dihafal; dalam contoh ini adalah Surah Al-Fil Ayat 1 yang

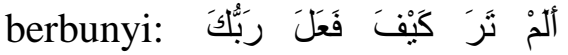
بأصنحَابِ القِيل

2)Ayat tersebut dipenggal menjadi ألخ

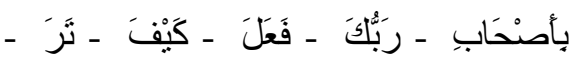
الفِيل

3)Selanjutnya, guru tahfizh mentaqqikan potongan pertama yaitu kata ألم kepada siswanya sampai siswa hafal. Setelah siswa hafal potongan pertama tersebut, dilanjutkan ke potongan kedua yaitu . نَرَ Setelah siswa hafal kata تَرَ lalu kemudian guru tahfih melanjutkan mentalaqqikan katakata selanjutnya sampai satu ayat itu selesai yaitu رَبَّكَ - فَعَلَ - كَيْنَ بأُصنحَاب الفِيل

4)Langkah terakhir adalah menggabungkan potonganpotongan tersebut menjadi satu ayat yang utuh, lalu mentalaqqikan 1 ayat utuh tersebut kepada siswa sampai siswa hafal.
Dalam observasi lapangan, peneliti melihat langung bagaimana guru tahfizh memotong ayat-ayat yang akan dihafalkan kepada siswa-siswi SDIT DOD Deli Serdang. Pada pelaksanaanya, peneliti melihat siswa-siswi sangat antusias mengikuti langkah-langkah penghafalkan ayat yang telah dipotong menjadi beberapa kata-kata tersebut. Melihat hal tersebut, peneliti sependapat dengan apa yang disampaikan di atas bahwa metode ini efektif untuk siswa Kelas I SDIT DOD Deli Serdang.

Selain metode di atas, untuk kelas memiliki beberapa strategi dan metode pembelajaran tahfizh Al-Qur'an yang berbeda dengan apa yang diimplementasikan di Kelas I. menurutnya, metode ini akan menyetarakan hafalan AlQur'an untuk semua siswa. Adapun langkah-langkahnya adalah sebagai berikut:

1) Membuat siswa-siswi nyaman dengan kegiatan-kegiatan permainan (baik terstruktur maupun bebas).

2) Setelah siswa duduk nyaman dan bisa fokus, selanjutnya siswa bisa diarahkan untuk memulai menghafal.

3) Metode menghafal di Kelas III ini adalah diawali dengan 
membaca berulang-ulang ayat yang hendak dihafal.

4) Setelah membaca berulang-ulang bersama-sama, misalkan 3 ayat pada surah An-Naba', selanjutnya siswa menghafal 3 ayat tersebut.

5) Siswa yang sudah bisa membaca Alquran akan dijadikan 1 kelompok menghafal an dibimbing oleh wali kelas.

6) Siswa yang masih Iqra' akan dijadikan menjadi 1 kelompok menghafal dan setoran, dibimbing oleh pendamping wali kelas.

Berbeda dengan kelas-kelas sebelumnya, wali Kelas V memaparkan metode pembelajaran tahfizh Al-Qur'an untuk siswa Kelas V dengan beberapa langkah penghafalan yang dijelaskan yaitu.

1) 15 menit pertama digunakan untuk mengulang hafalan (Muraja'ah) bersama-sama

2) Materi muraja'ah dibagi menjadi dua bagian yaitu murajaah hafalan surah-surah pendek dan muraja'ah hafalan yang dekat dengan materi yang akan dihafal.

3) Siswa diperintahkan menghafal materi pembelajaran (ayat-ayat yang telah ditetapkan) dengan mandiri.

4) Setelah menghafal secara mandiri, peserta didik menyetorkan hafalannya ke Muallimahnya (wali kelas sebagai penanggung jawab tahfizh Al-Qur'an)

5) Muallimah akan mengecek hafalan siswa dan akan memperbaikinya jika ada hafalan yang salah.

d. Penggunaan media pembelajaran

Tidak bisa dipungkiri bahwa salah satu strategi agar capaian pembelajaran mudah diraih adalah dengan memanfaatkan media pembelajaran. Kepala sekolah menjelaskan bahwa media pembelajaran tahfizh AlQur'an yang dimanfaatkan adalah Mushaf Alquran, Juz Amma (Mushaf kecil khusus juz 30 yang didalamnya juga terdapat metode cepat membaca Al-Qur'an), dan papan tulis yang tersedia. Demikian juga penjelasan Wali Kelas I bahwa tidak ada media khusus untuk program pembelajaran tahfizh Al-Qur'an di SDIT DOD Deli Serdang. Media pembelajaran yang digunakan hanyalah mushaf Al-Qur'an dan Juz Amma dan buku penghubung sebagai media komunikasi antara guru dengan orang tua siswa. 
Pendamping Wali Kelas III menyampaikan bahwa media yang digunakan dalam pelaksanaan program pembelajaran tahfizh Al-Qur'an khususnya di Kelas III adalah selain mushaf Al-Qur'an dan juz amma, juga menggunakan speaker aktif, terkadang memutar murottal lewat handphone.

e. Siswa mampu mengikuti target hafalan dalam setiap hari dan mampu menperdengarkan (setoran) hafalan baru sesuai target hafalan.

Target pencapaian yang diharapkan adalah minimal mampu menghafal 2 ayat dalam satu hari. Permasalahan yang mau diangkat adalah apakah siswa mampu menghafal dan mentasmi'kan 2 ayat tersebut dalam setiap hari? Kepala sekolah memberikan tanggapanya bahwa kepala sekolah dan jajarannya kesulitan memberikan penilaian terhadap pencapaian target hafalan setiap harinya. Kesulitan ini berasal dari tidak adanya target harian yang ditetapkan. Namun demikian, siswa yang tidak mampu menghafal dengan baik maka guru tahfizh akan mengajarkannya lebih fokus lagi, bahkan wakil kepala sekolah bidang tahfizh Al-Qur'an juga akan ikut membantu menghafalkan kepada anak-anak tersebut. Jika pencapaian hafalan yang tidak dapat diraih tersebut dipersentasikan, maka menurutnya dapat dikatakan $70 \%$ dapat mencapai target dan $30 \%$ belum bisa mencapai target.

Pada proses penghafalan ini, menurut beberapa siswa mengatakan bahwa ada di antara mereka yang sudah menghafal di rumah dengan orang tuanya, dan juga yang menghafalnya di sekolah. Terkait dengan menghafal di sekolah, siswa SDIT DOD Deli Serdang tersebut ada yang lebih suka menghafal dengan temannya, ada juga yang tidak bisa menghafal ribut-ribut, harus di tempat yang sunyi-sunyi. Pada permasalahan ini peneliti melihat bahwa semua siswa memiliki perbedaan dalam cara menghafal Al-Qur'an.

f. Siswa mampu mengulang/muraja'ah hafalannya Dalam pelaksanaan muraja'ah hafalan, siswa-siswi SDIT DOD Deli Serdang masih banyak yang lupa terhadap hafalannya. Terlebih pada siswa yag sudah memiliki hafalan lebih banyak, hal ini membuatnya lupa terhadap hafalan-hafalan lama. Siswa yang lupa pada hafalannya terlihat ketika di saat muraja'ah hafalan, siswa tersebut tidak buka mulut (tidak mengikuti muraja'ah bersama-sama).

Zubaidah Wali Kelas V Umar Bin Khattab mengungkapkan, bahwa penyebab hafalan hilang ini adalah tidak adanya kesadaran dari diri siswa untuk menjaga hafalan agar tidak hilang. Siswa baru bisa 
sadar dalam menjaga hafalan hanya ketika ada lomba-lomba tahfizh Al-Qur'an saja.

\section{Faktor pendukung program tahfizh} Al-Qur'an di SDIT DOD Deli

\section{Serdang}

Kepala sekolah menjelaskan terkait faktor pendukung keberhasilan pelaksanaan program pembelajaran tahfizh Al-Qur'an di SDIT DOD Deli Serdang adalah kemauan guru dalam memperbaiki kualitas diri mereka dalam tahsin dan tahfizh Al-Qur'an serta kepedulian orang tua. Bagi kepala sekolah, support yang ditunjukan oleh guru dalam bentuk kemauan mereka dalam belajar dan mengajarkan tahfizh Al-Qur'an membuat siswa juga bersemangat. Selanjutnya yang tidak kalah penting adalah kepedulian orang tua, menurutnya jika kedua belah pihak (sekolah dan orang tua) telah bersinergi maka keberhasilan sebuah program akan mudah dicapai.

Wakil kepala sekolah bidang kurikulum menjelaskan bahwa ada beberapa hal yang menjadi faktor pendukung pelaksanaan program pembelajaran tahfizh Al-Qur'an di SDIT DOD Deli Serdang, di antaranya adalah:

a. Penetapan program pembelajaran tahfizh Al-Qur'an sebagai bagian dari visi misi sekolah. Dengan adanya program tahfizh di visi misi membuat SDIT DOD Deli Serdang semangat dan memiliki tanggung jawab besar untu memproduksi produk-produk ungggulan dalam hafalan Al-Qur'an.

b. Semangat guru-guru dalam memperbaiki kualitas diri dalam membaca dan menghafal AlQur'an, baik dengan belajar ke Ma'had maupun tetap belajar dengan rekan sejawat. Adanya upgrade guru yang disediakan membuat guru berlomba-lomba menjadi yang terbaik, dan hal ini tentu berdampak pada hafalan siswa.

c. Dukungan orang tua. Sebagaimana diketahui bahwa rata-rata alasan orang tua siswa menitipkan anaknya sekolah di SDIT Deli Serdang adalah karena program pembelajaran tahfizh AlQur'an, sehingga orang tua punya keinginan menjadikan anaknya sebagai hafizh Al-Qur'an.

d. Komunikasi antar guru dan orang tua yang selalu mengingatkan dan mengkomunikasikan terkait perkembangan siswa siswi, terutama pada program pembelajaran tafizh Al-Qur'an.

Dari beberapa wawancara yang lain juga peneliti mendapatkan jawaban yang 
hakikatnya sama meski dengan narasi yang berbeda. Sehingga dalam hal ini, peneliti memberikan sebuah kesimpulan bahwa ada beberapa hal yang menjadi faktor pendukung pada pelaksanaan program pembelajaran tahfizh Al-Qur'an di SDIT DOD Deli Serdang, di antaranya:

a. Semangat guru memperbaiki kualitas Al-Qur'an-nya.

b. Peran dan dukungan orang tua

c. Komunikasi antar guru dan orang tua

d. Penetapan program pembelajaran tahfizh Al-Qur'an sebagai bagian dari visi misi sekolah, dan

e. Semangat siswa dan guru dalam menghafal dan muraja'ah.

Salah seorang tua siswa menelaskan bahwa orang tua yang aktif membantu siswa di rumah menjadi faktor pendukung penyelenggaraan program pembelajaran tahfizh Al-Qur'an di SDIT DOD Deli Serdang. Strategi yang dilakukan adalah dengan memanggil guru tahfizh (guru Alquran) ke rumah, dan menghidupkan speacker aktif murottal Al-Qur'an setiap pagi di rumah.

3. Faktor penghambat program tahfizh Al-Qur'an di SDIT DOD Deli Serdang

Kepala sekolah menjelaskan bahwa ada beberapa hal yang menjadi faktor penghambat pelaksanaan program pembelajaran tahfizh Al-Qur'an di SDIT DOD Deli Serdang, di antaranya:

a. Anggaran; minimnya anggaran sekolah untuk pelaksanaan program pembelajaran tahfizh Al-Qur'an membuat sedikit terkendala pada pelaksanaannya.

Karena kekurangan anggaran ini, sekolah akhirnya tidak bisa berbuat banyak, hanya memanfaatkan apa yang sudah ada saja.

b. Kualitas guru; sebagaimana diketahui bahwa guru yang bertanggung jawab atas pelaksanaan program pembelajaran tahfizh AlQur'an di SDIT DOD Deli Serdang bukanlah seorang guru yang profesional namun hanya memanfaatkan wali kelas dan guru mata pelajaran yang lainnya.

c. Siswa pindahan; terbukanya kesempatan bagi seluruh siswa karena adanya penerimaan siswa pindahan membuat capaian hafalan terkendala karena siswa pindahan datang tanpa membawa hafalan AlQur'an dan bacaan Al-Qur'an yang baik.

d. Kurang peran orang tua; Kurangnya dukungan orang tua dalam mengulang hafalan siswa di rumah. 
Meski ini bukan semua orang tua, namun nammpak jelas siswa yang ketinggalan hafalan itu akibat kurangnya peran orang tua.

Sementara itu, Eko Suanda, S.Pd Wakil Kepala Sekolah Bidang Kurikulum SDIT DOD Deli Serdang emngungkapkan, bahwa faktor penghambat dalam ranah kerja wakil kepala sekolah bidang kurikulum ada tiga hal, yaitu:

a. Kehadiran guru; pada masalah ini, jika guru yang telah ditetapkan sebagai guru tahfizh tidak dapat hadir karena berbagai macam alasan, pihak sekolah kesulitan mencari pengganti sementara di posisi yang ditinggalkan itu. Solusinya guru yang bertugas sebagai pendamping menjadi guru tahfizh yang harus mengelola semua siswa.

b. Kemampuan guru; kemampuan yang dimaksud adalah kemampuan guru dalam pembelajaran tahfizh Al-Qur'an. Dalam hal ini, solusi yang diberikan adalah merekrut guru yang telah bagus bacaan AlQur'an-nya.

c. Fasilitas sekolah seperti ruang kelas masih belum mendukung program pembelajaran tahfizh Al-Qur'an. Menurutnya, ada dua hal yang perlu diperhatikan dari kondisi ruang belajar saat ini. Kedua hal tersebut adalah pertama terkait luas ruangan yang menurutnya masih terbatas, dan kedua, jarak antar kelas satu dengan kelas yang lainnya masih terlalu dekat, sehingga ketika pelaksanaan muraja'ah hafalan misalnya, maka yang terjadi adalah suara yang berlaga, sehingga kelas mana yang bersuara keras akan menguasai pelaksanaan muraja'ah.

Selanjutnya faktor penghambat dalam pelaksanaan program pembelajaran tahfizh Al-Qur'an dalam pandangan wali kelas adalah faktor kurangnya perhatian orang tua sehingga siswa tidak mengulang atau muraja'ah di rumah. Adapun beberapa alasan siswa yang tidak muroja'ah di rumah yang dapat saya simpulkan adalah sebagaimana berikut ini:

a. Rata-rata memiliki orang tua karir sehingga pulang kerja bisa sore bahkan malam hari. Untuk menjemput siswa pulang dari sekolahpun terkadang bisa kesorean.

b. Kesadaran siswa untuk mengulang hafalan sendiri masih belum tibul sehingga masih banyak bermainmain. 
c. Alasan orang tua yang tidak memiliki Al-Qur'an atau Juz Amma di rumah, sehingga tidak muraja'ah hafalan.

d. Orang tua yang tidak memiliki kemampuan membaca Al-Qur'an sehingga tidak mampu menyimak hafalan anaknya di rumah.

e. Orang tua yang tidak hafal materi muraja'ah siswa, dan

f. Orang tua yang pulang kerja larut malam sehingga siswa tersebut harus tinggal sama orang lain, baik itu paman atau neneknya.

Penjelasan salah satu orang tua, bahwa ada beberapa permasalahan yang membuat pencapaian hafalan Al-Qur'an pada program pembelajaran tahfizh Al-Qur'an di SDIT DOD Deli Serdang terkendala, di antaranya:

a. Keterbatasan kemampuan orang tua dalam bacaan Al-Qur'an. Dalam hal ini, orang tua sudah berupaya membantu hafalan di rumah, namun karena belum bagus bacaan Al-Qur'an membuat hafalan terkendala karena di sekolah tidak melanjutkan hafalan tetapi memperbaiki bacaan yang telah dihafalkan.

b. Kesibukan merawat anak yang masih kecil. Hal ini tentu membuat seorang ibu rumah tangga membutuhkan energy ekstra dalam membagi waktu dengan mengajari dan menjaga adik.

c. Kecondongan anak bermain HP bahkan sudah pada taraf kecanduan. Hal ini terlihat dari bahasa yang sederhana "pantang terletak", itu artinya asal sudah luput dari pegangan orang tua, anak tersebut langsung mengambil HP dan memainkannya dan itu menjadi penyebab tidak melaksanakan muraja'ah hafalan lagi.

d. Kesibukan orang tua yang kelelahan setelah pulang ke rumah karena sudah seharian kerja di luar rumah sehingga tidak bisa lagi melihat dan memantau hafalan anaknya.

e. Keterbatasan ekonomi sehingga tidak bisa memanggil guru khusus untuk mengajari mengaji dan menghafalkan ke anak di rumah.

\section{KESIMPULAN}

Pelaksanaan program belum sesuai dengan yang direncanakan, guru belum menguasai materi pembelajaran, metode pembelajaran bervariasi dengan penyesuaian tingkat kemampuan siswa, belum menggunaan media pembelajaran 
berbasis elektronik, siswa belum mampu mengikuti target hafalan dan belum semua siswa mampu mengulang/muraja'ah hafalannya. Adapun faktor pendukung program tahfizh Al-Qur'an di SDIT DOD Deli Serdang; Kemauan guru dalam memperbaiki kualitas diri mereka dalam tahsin dan tahfizh Al-Qur'an, kepedulian orang tua, penetapan program pembelajaran tahfizh Al-Qur'an sebagai bagian dari visi misi sekolah, semangat guru-guru dalam memperbaiki kualitas diri dalam membaca dan menghafal Al-Qur'an, Komunikasi antar guru dan orang tua. Sedangkan faktor penghambat program tahfizh Al-Qur'an di SDIT DOD Deli Serdang; Minimnya anggaran, kualitas guru, siswa pindahan, kehadiran guru, kemampuan guru, kemampuan Al-Qur'an orang tua, fasilitas sekolah, rata-rata memiliki orang tua karir, belum ada kesadaran siswa untuk mengulang hafalan sendiri.

\section{DAFTAR PUSTAKA}

\section{Sumber dari Jurnal/Penelitian}

Aeni, A.N. (2017). Hifdz Alquran: Program Unggulan Full Day School dalam Membentuk Karakter Qurani Siswa SD. TARBAWY: Indonesian Journal of Islamic Education, 4(1).

Bisri, H. (2018). Pengelolaan Model Pembinaan Tahfizh Alquran. Journal Tadbir Muwahhid, 2(1).

Darama, E., dkk. (2018). Evaluation of 5th Grade English Curriculum According to Stufflebeam's Context, Input, Process, Product (CIPP) Model. International Journal of PsychoEducational Sciences, 7(2).

Falahudin, W. (2014). Pemanfaatan Media dalam Pembelajaran. Jurnal Lingkar Widyaiswara. 1(4).

Hakim, L. (2012). Internalisasi Nilai-Nilai Agama Islam dalam Pembentukan Sikap dan Prilaku Siswa Sekolah Islam Terpadu Al-Muttaqin Kota Tasik Malaya. Jurnal Pendidikan Agama Islam-Ta'lim, 10(1).

Saihu dan Rohman, B. (2019). Pembentukan Karakter Melalui Model Pendidikan Transformatife Learning pada Santri di Pondok Pesantren Nurul Ikhlas Bali. Edukasi Islami: Jurnal Pendidikan Islam, 08(02).

Saptadi, H. (2012). Faktor-Faktor Pendukung Kemampuan Menghafal Alquran dan Implikasinya dalam Bimbingan dan Konseling. Jurnal Bimbingan Konseling, Vol. 1(2).

Zhang, G., dkk. (2011). Using the Context, Input, Process, and Product Evaluation Model (CIPP) as a Comprehensive Framework to Guide the Planning, Implementation, and Assessment of Service-learning Programs. Journal of Higher Education Outreach and Engagement, 15(4).

\section{Sumber dari Buku}

Alaydroes, F., dkk. (t.t.). Kekhasan Sekolah Islam Terpadu; Standar Mutu. Jakarta: Tim Mutu JSIT Indonesia.

Al-Makhtum, S. dan YadiIradi. (2017). Karantina Hafal Alquran Sebulan. Ponorogo: Alam Pena.

Al-Qatthan, M. (2017). Dasar-dasar Ilmu Alquran. Jakarta: Ummul Qura.

Creswell, J.W. (2003). Research Design: Qualitative, Quantitative, and Mixed 
Methods Approaches. callifornia: Sage Publications.

Shihab, M.Q. (2009). Tafsir Al-Misbah: Pesan, Kesan dan keserasian Alquran. Ciputat: Lentera Hati.

Zulkifli, M.Y. dan Ahmad, M.Y.N. (2016). Memperkasa Generasi Penghafal Alquran. Center of Quranic Universiti Malaya: Darul Quran Jakim.

\section{Hasil Wawancaara}

Wawancara dengan Kepala Sekolah SDIT

DOD Deli Serdang di Kantor Kepala Sekolah, Tanggal 6 Agustus 2019.

Wawancara dengan Wali Kelas VI Abu Bakar Ash-Shiddiq di ruang kelas VI Abu Bakar Ash-Shiddiq pada Tanggal 27 Agustus 2019.

Wawancara dengan Wali Kelas V Umar Bin Khattab, di Kantor Wakil Kepala Sekolah Bidang Kurikulum, tanggal 28 Agustus 2019.

Wawancara dengan Wali Kelas I Muadz Bin Jabal di ruang Kelas I Muadz Bin Jabal, tanggal 6 Agustus 2019.

Wawancara dengan beberapa siswa Kelas VI yaitu Rizky Satriani Riandri Putra, Muhammad Faqih Rahman, Luqman Aufaradhi dan Nur Azizah, di Kelas VI Abu Bakar Ash-Shiddiq, tanggal 3 Desember 2019.

Wawanncara dengan wali siswa dari Aqilah Ashro Zhofiroh Lubis siswa kelas V wawancara di ruang tunggu SDIT DOD Deli Serdang, tanggal 29 Nopember 2019.

Wawancara dengan Wakil Kepala Sekolah Bidang Kurikulum SDIT DOD Deli Serdang, wawancara di Kantor Wakil Kepala Sekolah Bidang Kurikulum, tanggal 14 Agustus 2019.

Wawancara dengan Pendamping Wali Kelas III Zubair Bin Awwam di Kantor Wakil Kepala Sekolah Bidang
Kurikulum pada tanggal 28 Agustus 2019.

Wawancara dengan Pendamping Wali Kelas III Zubair Bin Awwam di Kantor Wakil Kepala Sekolah Bidang Kurikulum pada tanggal 28 Agustus 2019.

Wawancara dengan wali siswa dari Jannah Riandini, siswa Kelas VI Abu Bakar Ash-Shiddiq di ruang tunggu SDIT DOD Deli Serdang pada tanggal 29 Nopember 2019.

Observasi lapangan pada tanggal 26 Agustus 2019. 